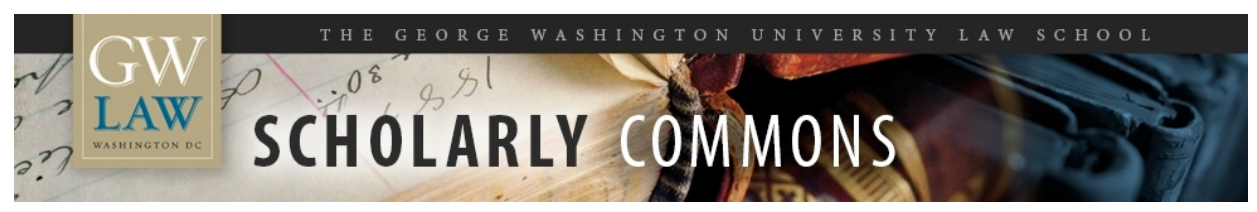

\title{
Introduction to the Essays of Warren Buffett: Lessons for Corporate America
}

Lawrence A. Cunningham

George Washington University Law School, lacunningham@law.gwu.edu

Follow this and additional works at: https://scholarship.law.gwu.edu/faculty_publications

Part of the Law Commons

\section{Recommended Citation}

Lawrence A. Cunningham, Introduction to the Essays of Warren Buffett: Lessons for Corporate America, 19 Cardozo L. Rev. 5 (1997).

This Article is brought to you for free and open access by the Faculty Scholarship at Scholarly Commons. It has been accepted for inclusion in GW Law Faculty Publications \& Other Works by an authorized administrator of Scholarly Commons. For more information, please contact spagel@law.gwu.edu. 


\section{THE ESSAYS OF WARREN BUFFETT: \\ LESSONS FOR CORPORATE AMERICA}

\section{Lawrence A. Cunningham*}

Experienced readers of Warren Buffett's letters to the shareholders of Berkshire Hathaway Inc. have gained an enormously valuable informal education. The letters distill in plain words all the basic principles of sound business practices. On selecting managers and investments, valuing businesses, and using financial information profitably, the writings are broad in scope, and long on wisdom.

Until now, however, the letters existed in a format that was not easily accessible and not organized in any thematic way. Consequently, the ideas have not been given the more widespread attention they deserve. The motivation for this compendium and for the symposium featuring it is to correct an inefficiency in the marketplace of ideas by disseminating the essays to a wider audience.

The central theme uniting Buffett's lucid essays is that the principles of fundamental valuation analysis, first formulated by his teachers Ben Graham and David Dodd, should guide investment practice. Linked to that theme are management principles that define the proper role of corporate managers as the stewards of invested capital, and the proper role of shareholders as the suppliers and owners of capital. Radiating from these main themes are practical and sensible lessons on mergers and acquisitions, accounting, and taxation.

Many of Buffett's lessons directly contradict what has been taught in business and law schools during the past thirty years, and what has been practiced on Wall Street and throughout corporate America during that time. Much of that teaching and practice eclipsed what Graham and Dodd had to say; Buffett as their prodigal pupil, stalwartly defended their views. The defenses run from an impassioned refutation of modern finance theory, to convincing demonstrations of the deleterious effects of using stock options to compensate managers, to persuasive arguments about the exaggerated benefits of synergistic acquisitions and cash flow analysis.

Buffett has applied the traditional principles as chief executive officer of Berkshire Hathaway, a company with roots in a group of textile operations begun in the early 1800s. Buffett took the helm of Berkshire in 1964, when its book value per share was \$19.46 and its intrinsic value per share far lower. Today, its book value per share is nearly \$20,000 and its intrinsic value far higher. The growth rate in book value per share during that period is $23.8 \%$ compounded annually.

\footnotetext{
* Cunningham is Professor of Law, George Washington University Law School; when this Introduction was prepared in 1996-97, he was serving as Visiting Associate Professor at George Washington and as Associate Professor at Benjamin N. Cardozo School of Law and, in the interim, served as Professor of Law \& Business at Boston College Law School.
} 
Berkshire is now a holding company engaged in a variety of businesses, not including textiles. Berkshire's most important business is insurance, carried on principally through its $100 \%$ owned subsidiary, GEICO Corporation, the seventh largest auto insurer in the United States. Berkshire publishes The Buffalo News and owns other businesses that manufacture or distribute products ranging from encyclopedias, home furnishings, and cleaning systems, to chocolate candies, footwear, uniforms, and air compressors. Berkshire also owns substantial equity interests in major corporations, including American Express, Coca-Cola, Walt Disney, Freddie Mac, Gillette, The Washington Post, Wells Fargo, and McDonald's.

Buffett and Berkshire Vice Chairman Charlie Munger have built this \$50 billion enterprise by investing in businesses with excellent economic characteristics and run by outstanding managers. While they prefer negotiated acquisitions of $100 \%$ of such a business at a fair price, they take a "double-barreled approach" of buying on the open market less than $100 \%$ of such businesses when they can do so at a pro-rata price well below what it would take to buy $100 \%$.

The double-barreled approach has paid off handsomely. The value of marketable securities in Berkshire's portfolio, on a per share basis, increased from \$4 in 1965 to over $\$ 22,000$ in 1995, a 33.4\% annual increase. Per share operating earnings increased in the same period from just over $\$ 4$ to over $\$ 258$, a $14.79 \%$ annual increase. These extraordinary results continue, in 1996 increasing by $29 \%$ and $63.2 \%$, respectively. According to Buffett, these results follow not from any master plan but from focused investing - allocating capital by concentrating on businesses with outstanding economic characteristics and run by first-rate managers.

$$
* * * * *
$$

Buffett views Berkshire as a partnership among him, Munger and other shareholders, and virtually all his $\$ 15$-plus billion net worth is in Berkshire stock. His economic goal is long-term - to maximize Berkshire's per share intrinsic value by owning all or part of a diversified group of businesses that generate cash and above-average returns. In achieving this goal, Buffett foregoes expansion for the sake of expansion and foregoes divestment of businesses so long as they generate some cash and have good management.

Berkshire retains and reinvests earnings when doing so delivers at least proportional increases in per share market value over time. It uses debt sparingly and sells equity only when it receives as much in value as it gives. Buffett penetrates accounting conventions, especially those that obscure real economic earnings.

These owner-related business principles, as Buffett calls them, are the organizing themes of the accompanying essays. As organized, the essays constitute an elegant and instructive manual on management, investment, finance, and accounting. Buffett's basic principles form the framework for a rich range of positions on the wide variety of issues 
that exist in all aspects of business. They go far beyond mere abstract platitudes. It is true that investors should focus on fundamentals, be patient, and exercise good judgment based on common sense. In Buffett's essays, these advisory tidbits are anchored in the more concrete principles by which Buffett lives and thrives.

Many people speculate on what Berkshire and Buffett are doing or plan to do. Their speculation is sometimes right and sometimes wrong, but always foolish. People would be far better off not attempting to ferret out what specific investments are being made at Berkshire, but thinking about how to make sound investment selections based on Berkshire's teaching. That means they should think about Buffett's writings and learn from them, rather than try to emulate Berkshire's portfolio.

Buffett modestly confesses that most of the ideas expressed in his essays were taught to him by Ben Graham. He considers himself the conduit through which Graham's ideas have proven their value. In allowing me to prepare this material, Buffett said that I could be the popularizer of Graham's ideas and Buffett's application of them. Buffett recognizes the risk of popularizing his business and investment philosophy. But he notes that he benefited enormously from Graham's intellectual generosity and believes it is appropriate that he pass the wisdom on, even if that means creating investment competitors. To that end, my most important role has been to organize the essays around the themes reflected in this collection. This introduction to the major themes encapsulates the basics and locates them in the context of current thinking. The essays follow.

\section{Corporate Governance}

For Buffett, managers are stewards of shareholder capital. The best managers think like owners in making business decisions. They have shareholder interests at heart. But even first-rate managers will sometimes have interests that conflict with those of shareholders. How to ease those conflicts and to nurture managerial stewardship have been constant objectives of Buffett's forty-year career and a prominent theme of his essays. The essays address some of the most important governance problems.

The first is not dwelt on in the essays but rather permeates them: it is the importance of forthrightness and candor in communications by managers to shareholders. Buffett tells it like it is, or at least as he sees it. That quality attracts an interested shareholder constituency to Berkshire, which flocks to its annual meetings in increasing numbers every year. Unlike what happens at most annual shareholder meetings, a sustained and productive dialogue on business issues results.

Besides the owner-orientation reflected in Buffett's disclosure practice and the owner-related business principles summarized above, the next management lesson is to dispense with formulas of managerial structure. Contrary to textbook rules on organizational behavior, mapping an abstract chain of command on to a particular business situation, according to Buffett, does little good. What matters is selecting people who are able, honest, and hard-working. Having first-rate people on the team is more 
important than designing hierarchies and clarifying who reports to whom about what and at what times.

Special attention must be paid to selecting a CEO because of three major differences Buffett identifies between CEOs and other employees. First, standards for measuring a CEO's performance are inadequate or easy to manipulate, so a CEO's performance is harder to measure than that of most workers. Second, no one is senior to the CEO, so no senior person's performance can be measured either. Third, a board of directors cannot serve that senior role since relations between CEOs and boards are conventionally congenial.

Major reforms are often directed toward aligning management and shareholder interests or enhancing board oversight of CEO performance. Stock options for management were touted as one method; greater emphasis on board processes was another. Separating the identities and functions of the Chairman of the Board and the CEO or appointment of standing audit, nominating and compensation committees were also heralded as promising reforms. None of these innovations has solved governance problems, however, and some have exacerbated them.

The best solution, Buffett instructs, is to take great care in identifying CEOs who will perform capably regardless of weak structural restraints. Outstanding CEOs do not need a lot of coaching from owners, although they can benefit from having a similarly outstanding board. Directors therefore must be chosen for their business savvy, their interest, and their owner-orientation. According to Buffett, one of the greatest problems among boards in corporate America is that members are selected for other reasons, such as adding diversity or prominence to a board.

Most reforms are painted with a broad brush, without noting the major differences among types of board situations that Buffett identifies. For example, director power is weakest in the case where there is a controlling shareholder who is also the manager. When disagreements arise between the directors and management, there is little a director can do other than to object and, in serious circumstances, resign. Director power is strongest at the other extreme, where there is a controlling shareholder who does not participate in management. The directors can take matters directly to the controlling shareholder when disagreement arises.

The most common situation, however, is a corporation without a controlling shareholder. This is where management problems are most acute, Buffett says. It would be helpful if directors could supply necessary discipline, but board congeniality usually prevents that. To maximize board effectiveness in this situation, Buffett believes the board should be small in size and composed mostly of outside directors. The strongest weapon a director can wield in these situations remains his or her threat to resign.

All these situations do share a common characteristic: the terrible manager is a lot easier to confront or remove than the mediocre manager. A chief problem in all governance structures, Buffett emphasizes, is that in corporate America evaluation of 
chief executive officers is never conducted in regular meetings in the absence of that chief executive. Holding regular meetings without the chief executive to review his or her performance would be a marked improvement in corporate governance.

Evaluating CEO performance is even harder than it may seem. Both short-term results and potential long-term results must be assessed. If only short-term results mattered, many managerial decisions would be much easier, particularly those relating to businesses whose economic characteristics have eroded. For an extreme but not atypical example, consider Al Dunlop's aggressive plan to turn around ailing Sunbeam. Dunlop fired half of Sunbeam's workers and closed or consolidated more than half its facilities, including some engaged in the textile business in New England. Boasting that he was attacking the entire company, Dunlop declared that his plan was as carefully plotted as the invasion of Normandy. Driven solely by the primacy of the short-term bottom line, that decision was easy.

The decision is much harder, however, if you recognize that superior long-term results can flow from earning the trust of social communities, as Buffett's consideration of the anxieties of plant closings suggests. The economic characteristics of Berkshire's old textile business had begun to erode by the late 1970s. Buffett had hoped to devise a reversal of its misfortunes, noting how important Berkshire's textile business was to its employees and local communities in New England, and how able and understanding management and labor had been in addressing the economic difficulties. Buffett kept the ailing plant alive through 1985, but a financial reversal could not be achieved and Buffett eventually closed it. Whether Buffett would approve of Dunlop-style short-termism is not clear, but his own style of balancing short-term results with long-term prospects based on community trust is certainly different. It is not easy, but it is intelligent.

Sometimes management interests conflict with shareholder interests in subtle or easily disguised ways. Take corporate philanthropy, for example. At most major corporations, management allocates a portion of corporate profit to charitable concerns. The charities are chosen by management, for reasons often unrelated either to corporate interests or shareholder interests. Most state laws permit management to make these decisions, so long as aggregate annual donations are reasonable in amount, usually not greater than $10 \%$ of annual net profits.

Berkshire does things differently. Shareholders designate charities to which the corporation donates. Nearly all shareholders participate in allocating millions of dollars per year to charitable organizations of their choice. This is an imaginative practical response to a tension that is at the core of the management-shareholder relationship. It is surprising that other American corporations do not follow this model of corporate charitable giving. Part of the reason may be the lack of long-term ownership orientation that characterizes the shareholder profiles of many American corporations. If so, this demonstrates a cost of the short-term mentality of America's investment community.

The plan to align management and shareholder interests by awarding executives stock options not only was oversold, but also subtly disguised a deeper division between 
those interests that the options created. Many corporations pay their managers stock options whose value increases simply by retention of earnings, rather than by superior deployment of capital. As Buffett explains, however, simply by retaining and reinvesting earnings, managers can report annual earnings increases without so much as lifting a finger to improve real returns on capital. Stock options thus often rob shareholders of wealth and allocate the booty to executives. Moreover, once granted, stock options are often irrevocable, unconditional, and benefit managers without regard to individual performance.

It is possible to use stock options to instill a managerial culture that encourages owner-like thinking, Buffett agrees. But the alignment will not be perfect. Shareholders are exposed to the downside risks of sub-optimal capital deployment in a way that an option holder is not. Buffett therefore cautions shareholders who are reading proxy statements about approving option plans to be aware of the asymmetry in this kind of alignment. Many shareholders rationally ignore proxy statements, but this subject should really be on the front-burner of shareholders, particularly shareholders of those institutions that periodically engage in promoting corporate governance improvements.

Buffett emphasizes that performance should be the basis for executive pay decisions. Executive performance should be measured by profitability, after profits are reduced by a charge for the capital employed in the relevant business or earnings retained by it. If stock options are used, they should be related to individual performance, rather than corporate performance, and priced based on business value. Better yet, as at Berkshire, stock options should simply not be part of an executive's compensation. After all, exceptional managers who earn cash bonuses based on the performance of their own business can simply buy stock if they want to; if they do, they "truly walk in the shoes of owners," Buffett says.

\section{Corporate Finance and Investing}

The most revolutionary investing ideas of the past thirty years were those called modern finance theory. This is an elaborate set of ideas that boil down to one simple and misleading practical implication: it is a waste of time to study individual investment opportunities in public securities. According to this view, you will do better by randomly selecting a group of stocks for a portfolio by throwing darts at the stock tables than by thinking about whether individual investment opportunities make sense.

One of modern finance theory's main tenets is modern portfolio theory. It says that you can eliminate the peculiar risk of any security by holding a diversified portfolio, that is, it formalizes the folk slogan "don't put all your eggs in one basket." The risk that is left over is the only risk for which investors will be compensated, the story goes.

This leftover risk can be measured by a simple mathematical term-called betathat shows how volatile the security is compared to the market. Beta measures this volatility risk well for securities that trade on efficient markets, where information about 
publicly traded securities is swiftly and accurately incorporated into prices. In the modern finance story, efficient markets rule.

Reverence for these ideas was not limited to ivory tower academics, in colleges, universities, business schools, and law schools, but became standard dogma throughout financial America in the past thirty years, from Wall Street to Main Street. Many professionals still believe that stock market prices always accurately reflect fundamental values, that the only risk that matters is the volatility of prices, and that the best way to manage that risk is to invest in a diversified group of stocks.

Being part of a distinguished line of investors stretching back to Graham and Dodd which debunks standard dogma by logic and experience, Buffett thinks most markets are not purely efficient and that equating volatility with risk is a gross distortion. Accordingly, Buffett worried that a whole generation of MBAs and JDs, under the influence of modern finance theory, was at risk of learning the wrong lessons and missing the important ones.

A particularly costly lesson of modern finance theory was the proliferation of portfolio insurance-a computerized technique for readjusting a portfolio in declining markets. The promiscuous use of portfolio insurance helped precipitate the stock market crash of October 1987, as well as the market break of October 1989. It nevertheless had a silver lining: it shattered the modern finance story being told in business and law schools and faithfully being followed by many on Wall Street. Ensuing market volatility could not be explained by modern finance theory, nor could mountainous other phenomena relating to the behavior of small capitalization stocks, high dividend-yield stocks, and stocks with low price-earnings ratios. Growing numbers of skeptics emerged to say that beta does not really measure the investment risk that matters, and that capital markets are really not efficient enough to make beta meaningful anyway.

In stirring up the discussion, people started noticing Buffett's record of successful investing and calling for a return to the Graham-Dodd approach to investing and business. After all, for more than forty years Buffett has generated average annual returns of $20 \%$ or better, which double the market average. For more than twenty years before that, Ben Graham's Graham-Newman Corp. had done the same thing. As Buffett emphasizes, the stunning performances at Graham-Newman and at Berkshire deserve respect: the sample sizes were significant; they were conducted over an extensive time period, and were not skewed by a few fortunate experiences; no data-mining was involved; and the performances were longitudinal, not selected by hindsight.

Threatened by Buffett's performance, stubborn devotees of modern finance theory resorted to strange explanations for his success. Maybe he is just lucky- the monkey who typed out Hamlet - or maybe he has inside access to information that other investors do not. In dismissing Buffett, modern finance enthusiasts still insist that an investor's best strategy is to diversify based on betas or dart throwing, and constantly reconfigure one's portfolio of investments.

Buffett responds with a quip and some advice: the quip is that devotees of his 
investment philosophy should probably endow chairs to ensure the perpetual teaching of efficient market dogma; the advice is to ignore modern finance theory and other quasisophisticated views of the market and stick to investment knitting. That can best be done for many people through long-term investment in an index fund. Or it can be done by conducting hard-headed analyses of businesses within an investor's competence to evaluate. In that kind of thinking, the risk that matters is not beta or volatility, but the possibility of loss or injury from an investment.

Assessing that kind of investment risk requires thinking about a company's management, products, competitors, and debt levels. The inquiry is whether after-tax returns on an investment are at least equal to the purchasing power of the initial investment plus a fair rate of return. The primary relevant factors are the long-term economic characteristics of a business, the quality and integrity of its management, and future levels of taxation and inflation. Maybe these factors are vague, particularly compared with the seductive precision of beta, but the point is that judgments about such matters cannot be avoided, except to an investor's disadvantage.

Buffett points out the absurdity of beta by observing that "a stock that has dropped very sharply compared to the market ... becomes 'riskier' at the lower price than it was at the higher price"- that is how beta measures risk. Equally unhelpful, beta cannot distinguish the risk inherent in "a single-product toy company selling pet rocks or hula hoops from another toy company whose sole product is Monopoly or Barbie." But ordinary investors can make those distinctions by thinking about consumer behavior and the way consumer products companies compete, and can also figure out when a huge stock-price drop signals a buying opportunity.

Contrary to modern finance theory, Buffett's investment knitting does not prescribe diversification. It may even call for concentration, if not of one's portfolio, then at least of its owner's mind. As to concentration of the portfolio, Buffett reminds us that Keynes, who was not only a brilliant economist but also a brilliant investor, believed that an investor should put fairly large sums into two or three businesses he knows something about and whose management is trustworthy. On that view, risk rises when investments and investment thinking are spread too thin. A strategy of financial and mental concentration may reduce risk by raising both the intensity of an investor's thinking about a business and the comfort level he must have with its fundamental characteristics before buying it.

The fashion of beta, according to Buffett, suffers from inattention to "a fundamental principle: It is better to be approximately right than precisely wrong." Longterm investment success depends not on studying betas and maintaining a diversified portfolio, but on recognizing that as an investor, one is the owner of a business. Reconfiguring a portfolio by buying and selling stocks to accommodate the desired betarisk profile defeats long-term investment success. Such "flitting from flower to flower" imposes huge transaction costs in the forms of spreads, fees and commissions, not to mention taxes. Buffett jokes that calling someone who trades actively in the market an investor "is like calling someone who repeatedly engages in one-night stands a romantic." 
Investment knitting turns modern finance theory's folk wisdom on its head: instead of "don't put all your eggs in one basket," we get Mark Twain's advice from Pudd'nhead Wilson: "Put all your eggs in one basket—and watch that basket."

Buffett learned the art of investing from Ben Graham as a graduate student at Columbia Business School in the 1950s and later working at Graham-Newman. In a number of classic works, including The Intelligent Investor, Graham introduced some of the most profound investment wisdom in history. It rejects a prevalent but mistaken mind-set that equates price with value. On the contrary, Graham held that price is what you pay and value is what you get. These two things are rarely identical, but most people rarely notice any difference.

One of Graham's most profound contributions is a character who lives on Wall Street, Mr. Market. He is your hypothetical business partner who is daily willing to buy your interest in a business or sell you his at prevailing market prices. Mr. Market is moody, prone to manic swings from joy to despair. Sometimes he offers prices way higher than value; sometimes he offers prices way lower than value. The more manicdepressive he is, the greater the spread between price and value, and therefore the greater the investment opportunities he offers. Buffett reintroduces Mr. Market, emphasizing how valuable Graham's allegory of the overall market is for disciplined investment knitting - even though Mr. Market would be unrecognizable to modern finance theorists.

Another leading prudential legacy from Graham is his margin-of-safety principle. This principle holds that one should not make an investment in a security unless there is a sufficient basis for believing that the price being paid is substantially lower than the value being delivered. Buffett follows the principle devotedly, noting that Graham had said that if forced to distill the secret of sound investment into three words, they would be: margin of safety. Over forty years after first reading that, Buffett still thinks those are the right words. While modern finance theory enthusiasts cite market efficiency to deny there is a difference between price (what one pays) and value (what one gets), Buffett and Graham regard it as all the difference in the world.

That difference also shows that the term "value investing" is a redundancy. All true investing must be based on an assessment of the relationship between price and value. Strategies that do not employ this comparison of price and value do not amount to investing at all, but to speculation - the hope that price will rise, rather than the conviction that the price being paid is lower than the value being obtained. Many professionals make another common mistake, Buffett notes, by distinguishing between "growth investing" and "value investing." Growth and value, Buffett says, are not distinct. They are integrally linked since growth must be treated as a component of value.

Nor does the phrase "relational investing" resonate with Buffett. The term became popular on Wall Street and in the academy in the mid-1990s, describing a style of investing that is designed to reduce the costs of the separation of shareholder ownership from managerial control by emphasizing shareholder involvement and monitoring of management. Many people incorrectly identified Buffett and Berkshire as exemplars of 
this descriptive label. It is true that Buffett buys big blocks in a few companies and sticks around a long time. He also only invests in businesses run by people he trusts. But that is about as far as the similarity goes. If Buffett were pressed to use an adjective to describe his investment style, it would be something like "focused" or "intelligent" investing. Yet even these words ring redundant; the unadorned term investor best describes Buffett.

Other misuses of terms include blurring the difference between speculation and arbitrage as methods of sound cash management; the latter being very important for companies like Berkshire that generate substantial excess cash. Both speculation and arbitrage are ways to use excess cash rather than hold it in short-term cash equivalents such as commercial paper. Speculation describes the use of cash to bet on lots of corporate events based on rumors of unannounced coming transactions. Arbitrage, traditionally understood to mean exploiting different prices for the same thing on two different markets, for Buffett, describes the use of cash to take short-term positions in a few opportunities that have been publicly announced. It exploits different prices for the same thing at different times. Deciding whether to employ cash this way requires evaluating four common-sense questions based on information rather than rumor: the probability of the event occurring, the time the funds will be tied up, the opportunity cost, and the downside if the event does not occur.

In all investment thinking, one must guard against what Buffett calls the "institutional imperative." It is a pervasive force in which institutional dynamics produce resistance to change, absorption of available corporate funds, and reflexive approval of sub-optimal CEO strategies by subordinates. Contrary to what is often taught in business and law schools, this powerful force often interferes with rational business decisionmaking. The ultimate result of the institutional imperative is a follow-the-pack mentality producing industry imitators, rather than industry leaders - what Buffett calls a lemminglike approach to business.

All these investment principles are animated in Buffett's lively essays on junk and zero-coupon bonds and preferred stocks. Challenging both Wall Street and the academy, Buffett again draws on Graham's ideas to reject the "dagger thesis" advanced to defend junk bonds. The dagger thesis, using the metaphor of the intensified care an automobile driver would take facing a dagger mounted on the steering wheel, overemphasizes the disciplining effect that enormous amounts of debt in a capital structure exerts on management.

Buffett points to the large numbers of corporations that failed in the early 1990s recession under crushing debt burdens to dispute academic research showing that higher interest rates on junk bonds more than compensated for their higher default rates. He attributes this error to a flawed assumption recognizable to any first-year statistics student: that historical conditions prevalent during the study period would be identical in the future. They would not. Further illuminating the folly of junk bonds is an essay in this collection by Charlie Munger that discusses Michael Milken's approach to finance.

Wall Street tends to embrace ideas based on revenue-generating power, rather 
than on financial sense, a tendency that often perverts good ideas to bad ones. In a history of zero-coupon bonds, for example, Buffett shows that they can enable a purchaser to lock in a compound rate of return equal to a coupon rate that a normal bond paying periodic interest would not provide. Using zero-coupons thus for a time enabled a borrower to borrow more without need of additional free cash flow to pay the interest expense. Problems arise, however, when zero-coupon bonds started to be issued by weaker and weaker credits whose free cash flow could not sustain increasing debt obligations. Buffett laments, "as happens in Wall Street all too often, what the wise do in the beginning, fools do in the end."

The essays on preferred stock show the art of investing at its finest, emphasizing the economic characteristics of businesses, the quality of management, and the difficult judgments that are always necessary, but not always correct.

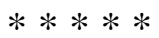

Buffett recalls that on the day Berkshire listed on the New York Stock Exchange in 1988, he told Jimmy Maguire, the specialist in Berkshire stock, "I will consider you an enormous success if the next trade in this stock is about two years from now." While Buffett jokes that Maguire "didn't seem to get enthused about that," he emphasizes that his mind-set when he buys any stock is "if we aren't happy owning a piece of that business with the Exchange closed, we're not happy owning it with the Exchange open." Berkshire and Buffett are investors for the long haul; Berkshire's capital structure and dividend policy prove it.

Unlike many CEOs, who desire their company's stock to trade at the highest possible prices in the market, Buffett prefers Berkshire stock to trade at or around its intrinsic value - neither materially higher nor lower. Such linkage means that business results during one period will benefit the people who owned the company during that period. Maintaining the linkage requires a shareholder group with a collective long-term, business-oriented investment philosophy, rather than a short-term, market-oriented strategy.

Buffett notes Phil Fisher's suggestion that a company is like a restaurant, offering a menu that attracts people with particular tastes. Berkshire's long-term menu emphasizes that the costs of trading activity can impair long-term results. Indeed, Buffett estimates that the transaction costs of actively traded stocks-broker commissions and marketmaker spreads - often amount to $10 \%$ or more of earnings. Avoiding or minimizing such costs is necessary for long-term investment success, and Berkshire's listing on the New York Stock Exchange helped contain those costs.

Corporate dividend policy is a major capital allocation issue, always of interest to investors but infrequently explained to them. Buffett's essays clarify this subject, emphasizing that "capital allocation is crucial to business and investment management." During 1997, Berkshire's common stock was priced in the market at nearly $\$ 50,000$ per share and the company's book value, earnings, and intrinsic value have steadily increased 
well in excess of average annual rates. Yet the company has never effected a stock split, and has not paid a cash dividend in three decades.

Apart from reflecting the long-term menu and minimization of transaction costs, Berkshire's dividend policy also reflects Buffett's conviction that a company's earnings payout versus retention decision should be based on a single test: each dollar of earnings should be retained if retention will increase market value by at least a like amount; otherwise it should be paid out. Earnings retention is justified only when "capital retained produces incremental earnings equal to, or above, those generally available to investors."

Like many of Buffett's simple rules, this one is often ignored by corporate managers, except of course when they make dividend decisions for their subsidiaries. Earnings are often retained for non-owner reasons, such as expanding the corporate empire or furnishing operational comfort for management.

Things are so different at Berkshire, Buffett said at the symposium, that under his test Berkshire "might distribute more than 100\% of the earnings," to which Charlie Munger chimed in "You're damn right." That has not been necessary, however, for throughout Buffett's stewardship at Berkshire, opportunities for superior returns on capital have been discovered, and exploited.

Stock splits are another common action in corporate America that Buffett points out disserve owner interests. Stock splits have three consequences: they increase transaction costs by promoting high share turnover; they attract shareholders with shortterm, market-oriented views who unduly focus on stock market prices; and, as a result of both of those effects, they lead to prices that depart materially from intrinsic business value. With no offsetting benefits, splitting Berkshire's stock would be foolish. Not only that, Buffett adds, it would threaten to reverse three decades of hard work that has attracted to Berkshire a shareholder group comprised of more focused and long-term investors than probably any other major public corporation.

Two important consequences have followed from Berkshire's high stock price and its dividend policy. First, the extraordinarily high share price impaired the ability of Berkshire shareholders to effect gifts of their equity interest to family members or friends, though Buffett has offered a few sensible strategies like bargain sales to donees to deal with that. Second, Wall Street engineers tried to create securities that would purport to mimic Berkshire's performance and that would be sold to people lacking an understanding of Berkshire, its business, and its investment philosophy.

In response to these consequences, Buffett and Berkshire did an ingenious thing. In mid-1996, Berkshire effected a recapitalization by creating a new class of stock, called the Class B shares, and sold it to the public. The Class B shares have 1/30th the rights of the existing Class A shares, except with respect to voting rights they have 1/200th of those of the A shares; and the Class B shares are not eligible to participate in the Berkshire charitable contributions program. Accordingly, the Class B shares should (and do) trade somewhere in the vicinity of 1/30th of the market price of the Class A shares. 
The Class A shares are convertible into Class B shares, giving Berkshire shareholders a do-it-yourself mechanism to effect a stock-split to facilitate gift giving and so on. More importantly, the Berkshire recapitalization would halt the marketing of Berkshire clones that contradict all the basic principles Buffett believes in. These clones investment trusts that would buy and sell Berkshire shares according to demand for units in the trust - would have imposed costs on shareholders. If held by people who do not understand Berkshire's business or philosophy, they would have caused spikes in Berkshire's stock price, producing substantial deviations between price and value.

The Class B shares are designed to be attractive only to investors who share Buffett's philosophy of focused investing. For example, in connection with the offering of the Class B shares, Buffett and Munger emphasized that Berkshire stock was, at that time, not undervalued in the market. They said that neither of them would buy the Class A shares at the market price nor the Class B shares at the offering price. The message was simple: do not buy these securities unless you are prepared to hold them for the long term. The effort to attract only long-term investors to the Class B shares appears to have worked: trading volume in the shares after the offering was far below average for Big Board stocks.

Some expressed surprise at Buffett and Munger's cautionary statement, since most managers tell the market that newly-issued equity in their companies is being offered at a very good price. You should not be surprised by Buffett and Munger's disclosure, however. A company that sells its stock at a price less than its value is stealing from its existing shareholders. Quite plausibly, Buffett considers that a crime.

\section{Mergers and Acquisitions}

Berkshire's acquisition policy is the double-barreled approach: buying portions or all of businesses with excellent economic characteristics and run by managers Buffett and Munger like, trust, and admire. Contrary to common practice, Buffett argues that in buying all of a business, there is rarely any reason to pay a premium.

The rare cases involve businesses with franchise characteristics - those that can raise prices rather easily and only require incremental capital investment to increase sales volume or market share. Even ordinary managers can operate franchise businesses to generate high returns on capital. The second category of rare cases is where extraordinary managers exist who can achieve the difficult feat of identifying underperforming businesses, and apply extraordinary talent to unlock hidden value.

These two categories are extremely limited, and certainly do not include or explain the hundreds of high-premium takeovers that occur annually. Buffett attributes high-premium takeovers outside those unusual categories to three motives of buyingmanagers: the thrill of an acquisition, the thrill of enhanced size, and excessive optimism about synergies.

In paying for acquisitions, Berkshire issues stock only when it receives as much in 
business value as it gives. Many other buyers, when not using cash or debt, violate this simple rule. Buffett notes that sellers in stock acquisitions measure the purchase price by the market price of the buyer's stock, not by its intrinsic value. If a buyer's stock is trading at a price equal to, say, half its intrinsic value, then a buyer who goes along with that measure gives twice as much in business value as it is getting. Its manager, usually rationalizing his or her actions by arguments about synergies or size, is elevating thrill or excessive optimism above shareholder interests.

Moreover, acquisitions paid for in stock are too often (almost always) described as "buyer buys seller" or "buyer acquires seller." Buffett suggests clearer thinking would follow from saying "buyer sells part of itself to acquire seller," or something of the sort. After all, that is what is happening; and it would enable one to evaluate what the buyer is giving up to make the acquisition.

If the worst thing to do with undervalued stock is to use it to pay for an acquisition, the best thing is to buy it back. Obviously, if a stock is selling in the market at half its intrinsic value, the company can buy $\$ 2$ in value by paying $\$ 1$ in cash. There would rarely be better uses of capital than that. Yet many more undervalued shares are paid to effect value-destroying stock acquisitions than are repurchased in valueenhancing stock buy-backs.

In contrast to sensible repurchases of undervalued stock, which serve owner interests, Buffett condemns management repurchases from individuals at premium prices to fend off unwanted acquisition overtures. Buffett forcibly shows that this practice of greenmail is simply another form of corporate robbery.

Nearly as reprehensible, a second Charlie Munger essay in this collection explains, were the cascades of leveraged buy-outs in the 1980s. Permissive laws made LBOs hugely profitable, Munger tells us, but the LBOs weakened corporations, put a heavy premium on cash generation to pay for enormous debt obligations, and raised the average cost of acquisitions.

Value-enhancing acquisitions are hard enough to find without the added burden of higher average costs for all of them. Indeed, most acquisitions are value-decreasing, Buffett says. Finding the best value-enhancing transactions requires concentrating on opportunity costs, measured principally against the alternative of buying small pieces of excellent businesses through stock market purchases. Such concentration is alien to the manager obsessed with synergies and size, but a vital part of Berkshire's double-barreled investment approach.

Berkshire has additional advantages in acquisitions: a high quality stock to pay with and a substantial amount of managerial autonomy to offer once a deal is done - both rare in an acquiring company, Buffett says. Buffett also puts his money where his mouth is, reminding prospective sellers that Berkshire has acquired many of its businesses from family or other closely-held groups, and inviting them to check with every previous seller about Berkshire's initial promises measured against its later actions. 


\section{Accounting and Taxation}

Buffett's essays provide an entertaining and illuminating tutorial on understanding and using financial information. In dissecting significant aspects of generally accepted accounting principles ("GAAP"), Buffett shows both their importance and limits in understanding any business or investment. Buffett demystifies key topics that highlight the important differences between accounting earnings and economic earnings, between accounting goodwill and economic goodwill, and between accounting book value and intrinsic value. These are important tools that must be in any investor's or manager's investment toolbox.

The most basic point to understand about accounting is that it is a form. As a form, it can be manipulated. Buffett shows just how severe the manipulation can be with a satire written by Ben Graham in the 1930s. The advanced bookkeeping methods Graham presents enable his phantom US Steel to report "phenomenally enhanced" earnings without cash outlays or changes in operating conditions or sales. Except in its lampooning spirit, Graham's illustration of accounting chicanery is not all that different from what is often seen coming out of corporate America.

Buffett emphasizes that useful financial statements must enable a user to answer three basic questions about a business: approximately how much a company is worth, its likely ability to meet its future obligations, and how good a job its managers are doing in operating the business. Buffett laments that GAAP conventions make these determinations difficult, and indeed almost any accounting system will be hard pressed to furnish completely accurate answers given the complexities of business. Acknowledging the monumental difficulty of inventing an accounting system superior to GAAP, Buffett articulates a range of concepts that go a longer way toward making financial information useful to investors and managers.

Consider a concept Buffett calls "look-through earnings." GAAP investment accounting calls for using the consolidation method for majority-owned equity, which means full reporting of all line items from the investee's financial statements on the parent's. For equity investments from $20 \%$ to 50\%, GAAP calls for reporting the investor's proportionate share of earnings of the investee on its statements; for investments of less than 20\%, GAAP provides that only dividends actually received by the investor be recorded, rather than any share of the investee's earnings. These accounting rules obscure a major factor in Berkshire's economic performance: the earnings generated by its investee companies are an enormous part of Berkshire's value, but would not be reported on its financial statements prepared using GAAP.

Recognizing that it is not the size of an equity investment that determines its value, but how the undistributed earnings are deployed, Buffett develops the concept of look-through earnings to gauge Berkshire's economic performance. Look-through earnings add to Berkshire's own net earnings the undistributed earnings in investee companies, less an incremental amount for taxes. Look-through earnings are not different 
from GAAP earnings for many businesses. But they are for Berkshire and probably are for many individual investors. Accordingly, individuals can adopt a similar approach for their own portfolios and try to design a portfolio that delivers the highest possible lookthrough earnings over the long term.

The difference between accounting goodwill and economic goodwill is wellknown, but Buffett's lucidity makes the subject refreshing. Accounting goodwill is essentially the amount by which the purchase price of a business exceeds the fair value of the assets acquired (after deducting liabilities). It is recorded as an asset on the balance sheet and then amortized as an annual expense, usually over forty years. So the accounting goodwill assigned to that business decreases over time by the aggregate amount of that expense.

Economic goodwill is something else. It is the combination of intangible assets, like brand name recognition, that enable a business to produce earnings on tangible assets, like plant and equipment, in excess of average rates. The amount of economic goodwill is the capitalized value of that excess. Economic goodwill tends to increase over time, at least nominally in proportion to inflation for mediocre businesses, and more than that for businesses with solid economic or franchise characteristics. Indeed, businesses with more economic goodwill relative to tangible assets are hurt far less by inflation than businesses with less of that.

These differences between accounting goodwill and economic goodwill entail the following insights. First, the best guide to the value of a business's economic goodwill is what it can earn on unleveraged net tangible assets, excluding charges for amortization of goodwill. Therefore when a business acquires other businesses, and the acquisitions are reflected in an asset account called goodwill, analysis of that business should ignore the amortization charges. Second, since economic goodwill should be measured at its full economic cost, i.e., before amortization, evaluation of a possible business acquisition should be conducted without regard to those amortization charges as well.

Buffett emphasizes, however, that the same does not hold for depreciation charges - these should not be ignored because they are real economic costs. He makes this point in explaining why Berkshire always shows its shareholders the results of operations with respect to acquired businesses net of any purchase price adjustments GAAP requires.

It is common on Wall Street to value businesses using a calculation of cash flows equal to (a) operating earnings plus (b) depreciation expense and other non-cash charges. Buffett regards that calculation as incomplete. After taking (a) operating earnings and adding back (b) non-cash charges, Buffett argues that you must then subtract something else: (c) required reinvestment in the business. Buffett defines (c) as "the average amount of capitalized expenditures for plant and equipment, etc., that the business requires to fully maintain its long-term competitive position and its unit volume." Buffett calls the result of (a) + (b) - (c) "owner earnings." 
When (b) and (c) differ, cash flow analysis and owner earnings analysis differ too. For most businesses, (c) usually exceeds (b), so cash flow analysis usually overstates economic reality. In all cases where (c) differs from (b), calculation of owner earnings enables one to appraise performance more accurately than would analysis of GAAP earnings, or cash flows affected by purchase price accounting adjustments. That is why Berkshire supplementally reports owner earnings for its acquired businesses, rather than rely solely on GAAP earnings figures, or cash flow figures.

A final example of Buffett's specialized toolkit is intrinsic value, "the discounted value of the cash that can be taken out of a business during its remaining life." Though simple to state, calculating intrinsic value is neither easy nor objective. It depends on estimation of both future cash flows and interest rate movements. But it is what ultimately matters about a business. Book value, in contrast, is easy to calculate, but of limited use. So too with market price, at least for most companies. Differences between intrinsic value and book value, and market price may be hard to pin down. They can go either way, but there will almost certainly be a difference.

GAAP has enough trouble. Yet two groups of people make it worse: those who try to overcome GAAP requirements by stretching their accounting imagination, and those who deliberately employ GAAP to facilitate financial fraud. The former is especially hard to deal with, as Buffett suggests in illustrating how debate on accounting for retiree benefits and stock options revealed the parochialism of many executives and accountants. For example, criticizing the view against treating stock options as expenses when granted, Buffett delivers this laconic argument: "If options aren't a form of compensation, what are they? If compensation isn't an expense, what is? And, if expenses shouldn't go into the calculation of earnings, where in the world should they go?"

Parochial positions on accounting can be economically disastrous, as the debate over accounting for retiree health care benefits attests. Until 1992, businesses that promised to pay for health care services to retired employees were not required by GAAP to record the associated obligation as a liability on their balance sheets. It thus made it easy to make such financial commitments, and many businesses made far more generous commitments to cover retiree health benefits than they would have had they been required to report the obligation. One consequence was a wave of bankruptcies, as businesses failed to meet their mounting and maturing obligations.

One clear lesson from Buffett's discussions of financial information is that accounting has inherent limits, even though it is absolutely essential. Despite enormous managerial leeway in reporting earnings and potential abuse, financial information can be of great use to investors. Buffett uses it everyday, and has spent billions of dollars doing it. Thus it is possible to make important investment decisions on the basis of available financial information if one exercises knowledgeable judgment. That judgment may include making adjustments to determine look-through earnings, owner earnings, and intrinsic value, and to show the real costs of stock options or other obligations that GAAP does not require to be recorded on the financial statements. 
Bringing this collection full circle, the concluding essays note the obvious but often overlooked tax advantages of long-term investment. Linking life's two certainties, the final essay includes one of Buffett's many jokes about his personal longevity: if enjoying life promotes longevity, he is jeopardizing Methuselah's record (969 years). At the symposium, someone asked what effect Buffett's death would have on Berkshire stock. Another answered, "a negative effect." Without missing a beat, Buffett quipped: "It won't be as negative for the holders as it will be for me."

The prominence of accounting discussions in Buffett's essays underscores that accounting policy and accounting decisions matter. That position is supported by Graham-Dodd fundamental valuation analysis. Yet it conflicts with modern finance theory's view that efficient markets will pierce accounting conventions to produce prices equal to values, and it also goes against the grain of what many MBA and JD students have been taught in the past few decades.

Buffett's essays can reeducate a generation of students, and continue the education of others. That is important because the gospel of modern finance theory that swept America in the past thirty years is still commonly preached. A lemming-like willingness to follow the crowd endures. Entailing the destruction of both leadership and independent thought, that weakness is the intellectual foe in the struggle Buffett's essays wage for intelligent, and focused investing. While the battle remains to be won, this compendium is intended to aid in the quest. 